\title{
Maslahah's Role as an Instrument for Revival of Ijtihad
}

\author{
HAYATULLAH LALUDDIN 1
}

\begin{abstract}
Islam presents a comprehensive system of life based on divine guidance. Its dynamism is due its general principles through which solutions for any conceivable situation could be sought. This is in line with the signification of the Quranic verse: "We have not neglected in the record a thing ..." This necessitates the adoption of an adequate methodology for the derivation of rulings from revealed source. A strict literal approach in understanding of the revealed text would not facilitate solutions for new issues due to the limitation of the text. Thus, maslahah, as a method of interpretation of revealed guidance can play a crucial role in providing solutions for new issues of legal and civilizational nature. Therefore, this article attempts to examine the instrumental role of maslahah in revitalization of Islamic thought. It also highlights the necessity for reviving ijtihad through which stagnation from intellectual spheres of Muslim world could be removed. Maslahah in this context provides an effective instrument for the purpose, hence, can play significant role in restoring originality and dynamism to Islamic thought.
\end{abstract}

Keywords: ijtihad, Islamic law, maslahah, public interest, shari'ah

Maslahah is considered to be the last theory in the development of Islamic jurisprudence. Literally, maslahah is an infinitive noun of the root salaha. It has different implication depending on the variety of context in which it is used. Saluha its verb form is used to indicate being good, right, virtuous, honest or to show the state of possessing these virtues. Its use in relational sense denotes a cause, a means, an occasion or a goal which is good or is for good (Lane' n.d.). When used as a noun it mean something considered good or useful (Rida' n.d.). Madarah (harm) and mafsadah (evil) are its antonyms. In general sense maslahah means welfare (Bosworth 1978). Technically, it means the consideration of the purposes of the law and the means of their realization. Its signification in this sense is clear from Imam al-Ghazali's statement: "what we mean by maslahah is protection of the purposes of Shari'ah which are: preservation of religion, life, reason, descendants and property" (al-Ghazali 1949). It also includes the means which lead to preservation of these five principles. Hence, maslahah in its essence is not only securing of benefits and prevention of harm, but it also needs to be in harmony with the objectives of the law-giver. Thus, as a method of interpretation of law it plays a crucial role in providing the ruling for new issues for which there exists no explicit evidence in the texts. It is therefore, a comprehensive method in its nature, for it extends the law to all areas of human activities. This underlying line of thought in the conception of maslahah renders it as a potential instrument for the revitalization Islamic thought. Therefore, this article attempts to analyse its role as a dynamic principle of the methodology of usul al-fiqh (the principle of Islamic jurisprudent) and

\footnotetext{
${ }^{1}$ Hayatullah Laluddin, Ph.D., Assistant Professor at Dept. of Economics, Kulliyyah of Economics and Management Sciences, International Islamic University, 53100 KUALA LUMPUR, Malaysia, email: hayatul@iiu.edu.my.
} 
as an instrument for revival of ijtihad. However, prior to this a brief sketch of the development of the usul al-fiqh is presented in the following.

\section{Historical Sketch}

Usul al-fiqh, according to the generally accepted view in traditional Islamic law, governs the judicial process and determines beforehand the methodology that is to be employed by the jurists for the discovery of the law and its application to a given set of facts. In fact, it provides a criterion for a correct understanding and evaluation, for almost every discipline of Islamic knowledge (Kamali 1999). In other words, usul al-fiqh lays down a methodology for jurists to be followed. For this reason it is indispensable for Muslim jurists to have a thorough grounding in Usul. The understanding of a detailed legal theory with its predetermined methodology had not been a prerequisite for the practice of the Islamic law prior to al-Shafi $i$, hence no legal theory had been systematically recorded till the last decade of the second century. However, the law during this period grew from the inner essential core into a highly consistent and mature system (Nyazee 1994). Even though nothing of the discipline now known as usul al-fiqh had emerged with its particular terminology, it does not mean that jurists did not adopt a methodology for the discovery of the law. It only means that no legal theory was expounded so as to understand and analyse this methodology. Nonetheless the various ijtihad processes employed during this period could be classified under the various forms of the principle of maslahah. Thus, the lack of an elaborate legal theory should not be taken to mean absence of a sound methodology. This is because the derivation of detailed rulings on particular issues from the sources of law was a matter of instinct, to the first generation of Muslims, just as they spoke Arabic instinctively. Therefore, there was no need for recording the methodology they used for deriving rulings.

Usul al-fiqh as a guideline for mujtahid in various ways of using source materials, was not used until Imam al-Shafi i put it to use in his new fiqh (al-Shafi i 1338H). From then onward skill in legal theory had to be a prerequisite for jurists. Al-Shafi i, beginning with the identification of the primary sources of Islamic law, secured a status for Sunnah of the prophet p.b.u.h as the second source of law. He also laid down rules for the literal interpretation of the text and for the extension of rulings by means of qiyas. His strict criterion in which linkage of derived rules to textual evidences was strongly required resulted in the rejection of some of the methods used by earlier jurists such as istihsan and modification of others such as ijma' (al'Alwani 1991). For this reason he is considered as the 'Champion of Sunnah' and the true author of Islamic jurisprudence..

The slightly modified version of al-Shafi i's theory called the classical legal theory of Islamic law was adopted by all jurists in the later period. The theory could not lead to any growth in new areas of the law. It led only to slightly modified, at times to somewhat restricted version of the law that existed before him. Perhaps he had a different purpose in mind which was to meet the need of the essential core of the law, i.e. the fixed part of the law, and not the flexible part of the law (Nyazee 1994). Hence it can be concluded that he constructed his new theory with the aim of ensuring the purity of the legal core by tying it to its sources, which was achievable through a strict theory of interpretation. However, he formulated his new theory by the end of the second century. It acquired a systematic form by the end of the fourth century but yet failed to bring any structural changes in the law. For it abided by strict literal interpretation. In the following, a short account of the theories developed in the course of the development of usul al-fiqh is presented. 


\section{Theory of General Principles}

The Hanafi's methodology is mainly based on the general principles which are derived from the Quran and the Sunnah, some of them were used by earlier jurists and are similar to maxims. Malik had a similar methodology. The reason is not that the two jurists were contemporaries but because the sources they used had much in common. The Hanafi's usul (principles) were more like the qawa id fiqhiyyah or the general principles of law. They referred to the general principles of Islamic law when encountering new circumstances. The general principles derive their strength from the definition of the general word ( $\mathrm{am}$ ) which they held to be definitive in its implication. Therefore, general words of commands and prohibitions in the nusus (textual sources), according to Hanafis, being definitive in their implication, cannot be restricted by evidence of weaker implications.

Even though the individual narration in the Hanafis view does not establish positive knowledge, it does create obligation for conduct (Aghnides 1981). However, when it contradicted the general principles, the Hanafi's stand was to interpret it in a manner which accords with the general principles. It shows that their method was analytical by nature and accommodative in its scope and implication. Thus, it can be concluded that Hanafi jurists usually took legal principles as the 'authoritative starting point for legal reasoning, from which they sought grounds for taking decision by the way of deduction' (al-Dabusi 1981). The Hanafi's theory revolves on the use of general principles stated explicitly in Qur'an or authentic Hadith and therefore is more flexible to accommodate new issues within its legal framework and provide adequate solutions. Even though, the general principle stated in the text is stronger than the derived principle but it can be strengthened by circumstantial evidence such as its maintenance by companion opinions and the method of ijma'. Therefore, the Hanafi's theory, consisting of the flexible general principles, led to the rapid development of the law and internal consistency of its system (Nyazee 1994).

The Hanafis particular concern for consistency enabled them to ward off the effect of traditions that were either weak or inconsistent with the overall system. This was made possible by adopting a method which analyses the tradition from two aspects: the content and the chain of transmission. Thus, some of the traditions even with weak isnad (chain of narration) were accepted when their text was found to be in conformity with general principles. The opinions of the companions, in Hanafi theory, were also considered to serve as a ground for determining the meaning of the text with the assumption that their close contact with prophet p.b.u.h enabled them to understand the texts better. The method based on the general principle did not apply to individual narration literally (Aghnides 1981).

\section{Theory of Strict Interpretation}

Al-Shafi i in his quest for securing a status for khabar wahid (individual narration) opposed systematically the constituent elements in the methods of earlier jurists and developed his own theory. He secured the position of the Sunnah as the second source of Shari'ah by asserting that the Sunnah governs the meaning of the Quran. In case of contradiction between the opinions of the companions, and khabar wahid, he preferred the latter, assuming that the opinions of the companions being an analogy based on the meaning of the Quran, is weaker in implication then the Sunnah. Therefore, to him the companion's opinion could neither be preferred over Sunnah nor could be considered as a basis for interpreting the Quranic text. But in respect of the point on which there existed consensus of the opinions he deems it impossible. While other Shafi'i's accepted ijma' in different form, such as using it to support the identification of underlying cause ('illah) as determined by them. Al-Shafi i views general word not to be of definitive 
implication, hence, restrictable by khabar wahid. By affirming this, he strengthened the position of khabar wahid and made it equal in its implication to that of the general word. The Hanafis in contrast to al-Shafi i, hold the implication of the general word to be definitive, hence not restrictable by khabar wahid.

Even though al-Shafi i was a staunch supporter of Sunnah, he did set certain conditions, such as the soundness of the chain of narration and its completeness for the acceptance of khabar wahid. The lacks of these conditions, according to him, render it invalid and hence cannot be considered as a source of ruling. He stipulated these conditions for the acceptance of khabar wahid to safeguard his theory. This is because he rendered the implication of the general word to be probable and hence restrictable by individual narration which is too probable in its implication. In such a situation jurists with a strong literalist tendency will try to erect the law on the basis of weak tradition and consequently putting an end to its consistency. It was also meant to build a shield against fabricated traditions and to ward off their effect on his theory.

Al-Shafi i accepted the opinions of the companions with reservation. He maintained that the opinion of a companion is not binding especially if it contradicts the Sunnah. Unlike the Hanafis who urged the interpretation of the Quran and of the Sunnah in the light of principles established by the companions, al-Shafi i urged that the Quran and the opinion of the companion should be interpreted in the light of authentic Sunnah. This is what he means by alSunnah Qadiyah 'ala al-Quran (Sunnah governs the meaning of the Quran) (al-Shafi i 1338H) He accepted qiyas and equated it to ijtihad. He recognizes only two types of qiyas: qiyas al-ma'na and qiyas al-shabh. He explains: qiyas is undertaken from two aspects, the first when a thing is included in the meaning (ma'na) of the asl. This is agreed upon. Then there may be a thing which has some similarity to those in the sources, it is therefore linked with the one closer to it or greater in similarity (al-Shafi i $1338 \mathrm{H}$ ). Qiyasal-Ma'na as described by al-Shafi'i is actually a literal method. He does not mention qiyas al-illah or the analogy which is used by later Muslim jurists and was presented in a refined form after al-Shafi i. However, later Shafi is attributed to him the method of qiyas al-illah and that of ikhalah by stretching some of the issues discussed by him. But al-Shafi i himself, by accepting only two methods of qiyas made his theory more strict and seem more or less literal. Thus al-Shafi'i's position towards the general word and its restrictability by khabar wahid, his view of the impossibility of ijma', his preference for khabar wahid over the companions opinion and his acceptance of only two types of qiyas, rendered his theory of interpretation more strict and literal.

\section{Theory of the Purposes of the Law}

The literal system of legal interpretation in fact falls back to the purposes of the law. The theory of the purposes of the law is claimed to be the last theory of interpretation. The core of the theory is the collective consideration of the texts to benefit from the spirit of the law, hence opening an avenue for its further development. The theory revolves on the interpretation of the law in the light of its purposes which is conducive to broadening the scope of legal rulings to all areas of human activities. The process, started by al-Shafi i jurists like al-Juwayni and al-Ghazali, and was further refined by other jurists. The theory is, in fact, a continuation and development of the concept of maslahah which was used by jurists of all schools but under different names (Mas`ud 1984). For instance, the Hanafis used it under the name of istihsan, Shafi'i's, before alGhazali, used it under the term of ikhalah (convincing opinion), Maliki used it under the name of istislah and sometime in the name of qiyas. The fact that the designation of the strict theories in a manner which hinders the extension of law beyond a limited sphere, in which the texts operate explicitly with some extension by the use of strict analogy, necessitate the structuring of a method through which solutions could be found for new issues of great concern to the Muslim 
community. Hence, great efforts were made by some jurists to discover such a method by which the accommodation of changes can be justified. This was also necessary because of the strong feeling of the Muslim community to regulate all of their activities by the dictate of Shari ah, and their conviction that nothing has been left out in the text, and so for every situation faced by human being a rule has to be discovered (Nyazee 1994). These all constitute a firm ground for the evolution of the theory of purpose of the law, and highlight its importance in the construction of a comprehensive methodology conducive to the revitalization of the concept of ijtihad.

Al-Ghazali's concept of maslahah as mentioned before, presents a viable method for deriving the law from the general principles. The theory derives its strength from the fact that it deals with preservation of the purposes of law. The theory is mainly based on two types of reasoning, in addition to the traditional methods of interpretation. They are: reasoning from a general principle and the reasoning based on a form of analogy which is wider than the syllogism. Actually the purposes of the law function as an interplay between the general principle and analogy (Nyazee 1994). Thus, the theory by virtue of it purposive nature could stretch the text of revelation to cover all areas of human activities and provide solution for the crisis of thought which arise out of narrow and inappropriate understanding of the revelation. This demonstrates its potentiality in facilitating the framework for structuring of a comprehensive method which could be used for provision of solution for all fields of human life based on revelation.

Al-Ghazali, systematizing the theory of the purposes of law, gave it the name maslahah. Hence, maslahah as a method of deriving ruling based on the consideration of the purpose of the law is considered to be comprehensive in its nature. For it not only relies on the literal implication of the text but also takes into consideration the spirit of the law and its general application. The general principles are of two kinds: the ones explicitly stated in the text and those derived from the text. The principles explicitly stated in the text also can be termed as Mu'athir Munasib principle, for they are mentioned explicitly in the texts and their underlying causes are in conformity with the purposes of the law. The derived principles are called Mula'im. They are derived directly from the text. In reality they are generalized principles with no specific underlying cause. They are flexible general principles with the determined underlying cause beneath them which act as genus for all the cases to which the hukm can be extended (Nyazee 1994). From the foregoing, it is clear that the theories developed in the course of the development of usul al-fiqh can be classified into three categories, the theory of general principles, the credit for which is due to the Hanafi school and Imam Malik, the theory of strict literal interpretation which is characterized with a strong tendency of tying legal rulings to textual basis, and the theory of the purposes of the law which functions under the mechanism of maslahah. It provides a vibrant theory in the Islamic legal system through which law can be extended to all areas of human activities. However, it is also clear that jurists in deriving a legal theory took two approaches: 1) to analyse and study the work of previous well known jurists and identify their methodology, as was the case with the Hanafi School, and 2) to lay down the rules of interpretation and abide by them strictly in deriving rulings. The later method was followed by Imam al-Shafi i who prescribed such rules mainly in his book al-Risalah.

Contemporary Islamic scholarship in order to deal with social complicated phenomena and to facilitate the derivation of rulings and concepts from Divine revelation needs to forge a new methodology. The general principles of the Islamic law provide the basic elements for such a methodology. It is therefore an indispensable task for Muslim intellectuals in order to keep abreast with changing situations and circumstances to work out such a methodology. In this direction the intellectuals cannot formulate their methods in the vacuum. They need to benefit from the elements of the methods used by previous scholars. In my opinion, one of the method 
through which the general principle could be identified and applied in a broader perspective is that of the systematically organized theory of maslahah as described by al-Ghazali. The vibrant theory of maslahah is the relevant method for the purpose mentioned. This theory provides a means of looking at the issues from a realistic point of view hence a suitable tool for understanding of Islamic system in the present context of the society.

Al-Ghazali, keeping in view the ever arising social changes and circumstances constructed his theory by incorporating the previous methods of interpretation, used by jurists before him. He designed the theory in a way that reflects the flexibility of the law and its ever growing and generative nature which could provide answers to the problems not explicitly provided for in the texts. Maslahah, therefore, due to its realistic nature in dealing with new circumstances, has much to offer for renewal of the principle of ijtihad. It equips the Muslim intellectuals with the means for formulation of a methodological and realistic approach, through which they can effectively deal with not only legal issues but also with social and civilizational issues based on the consideration Shari'ah's higher purposes, objectives and principles. Thus, positive contribution to the civilizational need of the society, highly depend on the designation of a dynamic fiqh which is responsive to the changing situations and which relies upon living ideas suited to the circumstances of the contemporary society. It is expected that this kind of fiqh can generate and restore creativity to the Muslim mind and take part in making marvellous contributions to the civilizational need of the world as a whole. The genius of the dynamic fiqh lies in the fact that it will enable every individual and every society to pass through its own special stage in the light of the broader Shari ah principles. Hence, it is expected that all Muslim intellectuals benefiting from the comprehensive methodology of scholars before them could revive ijtihad and contribute positive to materialize this objective and restore to ummah its position of leadership.

\section{Need for a New Methodology}

The absence of an adequate and comprehensive methodology in dealing with the texts resulted in a narrow understanding of the Islamic law and gradually led to its stagnation in terms of not being accommodative of new situations and circumstances. While humanity's great achievements in the field of science, have generated a great deal of changes and developments, to provide answers to the new issues arising as a result of such social changes, recourse has to be made to a sound and comprehensive methodology. Sticking to strict literal approach in analysing the issues concerned, cannot bring about a desired result. It rather depicts the Islamic thought as incapable of dealing with new circumstances and changes. Thus, awareness and sensitivity of the principles and approaches of thought, as well as of the principles, values and the purposes of Shariah, is a dire necessity for survival and positive contribution to the contemporary civilizational needs of the ummah. They are the only proper standards, for the vitality and preservation of the revelation, the Prophetic message and the Shari ah from all distortions and misinterpretations. At the same time, it ensures the integrity and freedom of the Muslim mind and methodology, hence facilitating the positive thinking and comprehensive understanding of the objectives of life, universe and humanity. It is not an exaggeration to say that preserving the Muslim mind and methodology is the same as preserving Islam itself (Abu Sulayman 1993). This could be justified on the ground that it is through the intellect that one comprehends and perceives the revelation, and the accurate and correct understanding depends on the use of a proper and adequate methodology. Maslahah therefore, as a tool of such characteristics could be used in extending the law to the sphere beyond the literal implications through inductive method, therefore, prove its potential role in revitalization of Islamic thought and civilization. 
It is an admitted fact that the ummah's previous glorious achievements were due to its adherence to the Islamic thinking and methodology. It was only due to its whole hearted conviction to Islam that allowed the ummah to establish its civilization and culture all over the world. Unfortunately the rift between the political sphere and the intellectual sphere in the history of Islamic thought caused a decline in the intellectual development of the ummah. By the passage of time the gap between the two grew wider and the intellectual leadership distancing itself from the political scene opted for isolation from the state's affairs. They busied themselves with theoretical aspects of Islam by dealing essentially with descriptive and lexical approaches to the interpretation of texts from the Quran and the Sunnah (Abu Sulayman 1993). By adapting this attitude they wanted to safeguard the sacred texts from misinterpretation and its misusing by the political leadership for the justification of their actions. But it lead to counterproductive effect manifested in theoretical conflict between the two, hence shifting the focus of Muslim intellectual activities from major issues of vital importance to minor issues of less importance. As a consequence of this state of affairs, the ummah is even now incapable of competing with other civilizations neither on the material nor on the intellectual levels. The conflict put an end to the spirit of cooperation between the two and gradually gave way to taqlid. This in its essence represents a great setback for the intellectual progress of the Muslim ummah. The impact of this blow to the intellectual activity was so severe that it paralyzed the Muslim mind and rendered it helpless to generate any further development to Muslim thought, hence losing its originality

Consequently, tendency of looking at the problems from narrow perspectives, emerging from a strict literal interpretation and the rift between political and intellectual spheres, resulted in a conservative approach in dealing with the text of the revelation. This trend remained a dominant phenomenon with the Islamic scholarship for centuries. This contributed to Islamic thought becoming distinctly retrospective, hence lost in the faint recollection of times past and the adoration of sacred relics. This state of affairs put the Muslim mind in stagnation and was not able to make any positive contributions in the field of thought and civilization. To get rid of this sorry state of affairs resort should be made to the dynamic methodology of Islamic thought which was applied by the early generation of Muslims. This requires the adaption of a comprehensive approach to understanding the early theories, and their applications in the early period of Islam with special regard to the dimension of time and place. Beside this the objective and higher purposes of Islam and proper relationship between them should be understood. In this manner firm foundation for the interaction of ummah with the contemporary life and society could be laid. Thus, the Muslim ummah will be able to keep pace with time and regain its past prestige and reputation (Abu Sulayman 1993). Bearing in mind the aggravating state of affairs caused by the closure of the door of ijtihad, it is therefore incumbent on the Muslims intellectual to reactivate ijtihad through adopting a comprehensive methodology. Those having the ability and the qualification for the undertaking of the task, have to give of their utmost efforts to revitalize the dynamic spirit of Islam and clear away the mist caused by stagnation and blind imitation. Ijtihad is the main factor in dynamism, mobility and the creative spirit of Islam. It is the principle of movement in the structure of Islam, as Iqbal holds. It reconciles the categories of permanence and change in life and represents spiritual eternity which manifests itself through variety and change (Iqbal 1965). Surely, the losing of such a dynamic principle is a paralyzing blow to the Islamic mentality.

Therefore, the revitalization of the Islamic thought depends heavily on the operationalization of the process of ijtihad from a new perspective in the present context of the world. Thus, it is through the actualization of the process of ijtihad that the Muslim ummah can regain its asalah and integrity. In the process the tendencies of talfiq and taqlid have to be done away with. Both talfiq and taqlid must give way to an original and an Islamic approach which is comprehensive in its nature and truly reflects the Islamic concepts, objectives and values. It also 
requires an independent Islamic intellectual inquiry nourished by Islamic social sciences that are distinguished by their sound sources and comprehensive premises and methodology (Abu Sulayman 1993). Islam is a living tradition which provides the well- spring of cultural renewal. Its potential for rejuvenation and renewal, and its all- embracing nature (Abu Fadl 1985) could be justified on the basis of maslahah as a source material and means for derivation of a critical rational tool, by means of which reorientation and renewal of global civilization could be materialized. This is due its potential for provision of solutions to the problems from a broader perspective on the basis of revealed knowledge.

In conclusion, the phenomenon of the closure of the door of Ijtihad and the rift between political and intellectual spheres brought about a great deal of stagnation in the intellectual sphere of Muslim world. The cause for such sorry state of affair lays in the separation between the political and intellectual leaderships. This put an end to the spirit of cooperation among them. Intellectual leadership retreating from the social and political scenes concentrated on personal aspects of Islam and took a strict literal approach in dealing with the Quran and the Sunnah. This etymological approach culminated in the stagnation of Islamic thought, hence, rendering it incapable of positive contribution in the field of science and civilizational need of the ummah. Thus, the urgency of need for forging a new methodology capable of analysing complicated social phenomenon, and facilitating the derivation of rulings and concepts from the Divine revelation become clear. This is required to restore dynamism to Islamic intellectual thought, hence its revitalization. Maslahah in this context presents a comprehensive and effective tool for revitalization of the concept of ijtihad, hence the removal of stagnation from intellectual sphere and restoring originality and dynamism to the Islamic thought.

\section{References}

Abu Fadl, M. 1985. Towards Global Cultural Renewal: Modernity and the Episteme of Transcendence. Herdon: IIIT.

Abu Sulayman, A. H. 1993. Crisis in the Muslim Mind. Translated by Yusuf Talal. Herndon: IIIT. Aghnides, N. 1981. An Introduction to Muhammadan Law. Lahore: Sang-e-Meel Publication. Al-'Alwani, Taha Jabir. 1991. Source Methodology in Islamic Jurisprudence. Edited by Yusuf Talal \& Anas S. Herdon: IIIT.

Bosworth, C. E. 1978. The Encyclopaedia of Islam. Vol. IV. Leiden: E.J. Brill. al-Dabusi, Abu Zayd 'Ubaid Allah Ibn `Umar Isa. n.d. Tasis al-Nazar. Cairo: Dar al-Fikr. al-Ghazali. 1983. Al-Mustasfa' min 'Ilm al-Usul. Vol.I Beirut: Dar al-Kutub al-'Ilmiyyah. Iqbal, Muhammad. 1965. Reconstruction of Religious Thought in Islam. Lahore. n.p. Kamali, M. H. 2009. Principles of Islamic Jurisprudence. Subang Jaya: 'Ilmiyah Publication. Lane, E. W. 1863. An Arabic-English Lexican. Vol. IV. London: William Norgat. Mas'ud, Khalid. n.d. Islamic Legal Philosophy. Islamabad: Islamic Research Centre. Nyazee, Imran. 1994. Theories of Islamic Law. Islamabad: Islamic Research Institute. Rida', Ahmad. n.d. Mu 'Jam Matn al-Lughah. Beirut: Dar Maktabat al-Hayah.

Al-Shafi i, Muhammad Ibn Idris. 1338A.H. Al-Risalah fi Usul al-Fiqh. Edited by Ahmad Muhammad Shakir. Cairo: Dar al-Fikr al-'Arabi. 